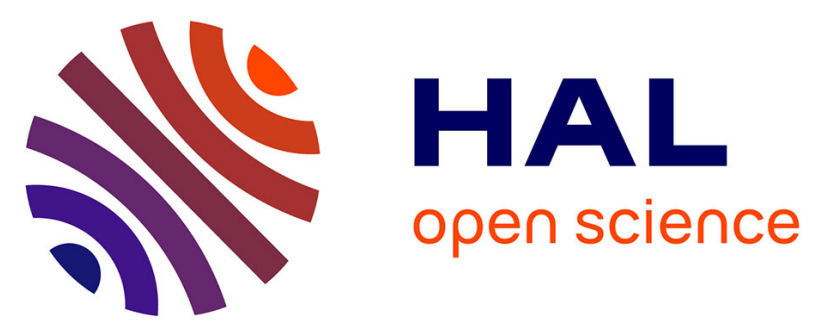

\title{
Morphological and physiological traits of Mediterranean sticklebacks living in the Camargue wetland ( Rhone river delta)
}

Khalid Rind, Quentin Rodriguez-barucg, Delphine Nicolas, Patricia Cucchi, Jehan-hervé Lignot

\section{To cite this version:}

Khalid Rind, Quentin Rodriguez-barucg, Delphine Nicolas, Patricia Cucchi, Jehan-hervé Lignot. Morphological and physiological traits of Mediterranean sticklebacks living in the Camargue wetland ( Rhone river delta). Journal of Fish Biology, 2020, 97 (1), pp.51-63. 10.1111/jfb.14323 . hal-03085876

\author{
HAL Id: hal-03085876 \\ https://hal.science/hal-03085876
}

Submitted on 7 Jan 2021

HAL is a multi-disciplinary open access archive for the deposit and dissemination of scientific research documents, whether they are published or not. The documents may come from teaching and research institutions in France or abroad, or from public or private research centers.
L'archive ouverte pluridisciplinaire $\mathbf{H A L}$, est destinée au dépôt et à la diffusion de documents scientifiques de niveau recherche, publiés ou non, émanant des établissements d'enseignement et de recherche français ou étrangers, des laboratoires publics ou privés. 


\section{Morphological and physiological traits of Mediterranean sticklebacks living in the} Camargue wetland (Rhone river delta)

Khalid Rind ${ }^{1}$, Quentin Rodriguez-Barucg ${ }^{3}$, Delphine Nicolas ${ }^{2}$, Patricia Cucchi ${ }^{3}$ Jehan-Hervé Lignot ${ }^{3}$

${ }^{1}$ Shaheed Benazir Bhutto University Shahee Benazirabad, Nawabshah, Pakistan

${ }^{2}$ La Tour du Valat, Arles, France

${ }^{3}$ University of Montpellier, Montpellier, France

Correspondence : Jehan-Hervé Lignot, University of Montpellier, MARBEC, PI. E. Bataillon, 34095 Montpellier, France.

Email: jehan-herve.lignot@umontpellier.fr

How to cite this article: Rind K, Rodriguez-Barucg Q, Nicolas D, Cucchi P, Lignot J-H. Morphological and

physiological traits of Mediterranean sticklebacks living in the Camargue wetland (Rhone river delta). J Fish Biol. 2020;1-13. https://doi.org/10.1111/jfb.14323

\section{Abstract}

Three-spined sticklebacks (Gasterosteus aculeatus L.) living at the southern limit of the species distribution range could possess specific morphological and physiological traits that enable these fish to live at the threshold of their physiological capacities. Morphological analysis was carried out on samples of sticklebacks living in different saline habitats of the Camargue area (Rhone delta, northern Mediterranean coast) obtained from 1993 to 2017. Salinity acclimation capacities were also investigated using individuals from freshwater-low salinity drainage canals and from mesohaline- euryhaline lagoons. Fish were maintained in laboratory conditions at salinity values close to those of their respective habitats: low salinity (LS, 5\%o) or seawater (SW, 30\%o). Fish obtained from a mesohaline brackish water lagoon (BW, 15\%o) were acclimated to SW or LS. Oxygen consumption rates and branchial Na+/K+-ATPase (NKA) activity (indicator of fish osmoregulatory capacity) were measured in these LS or SW control fish and in individuals subjected to abrupt SW or LS transfers. At all the studied locations, only the low-plated "leiurus" morphotype showed no spatial or temporal variations in their body morphology. Gill rakers were only longer and denser in fish sampled from the LS-freshwater (FW) drainage canals. All fish presented simi- lar physiological capacities. Oxygen consumption rates were not influenced by salin- ity challenge except in SW fish transferred to LS immediately and $1 \mathrm{~h}$ after transfer. However, and as expected, gill NKA activity was salinity dependent. Sticklebacks of the Camargue area sampled from habitats with contrasted saline conditions are homogenously euryhaline, have low oxygen consumption rates and do not appear to experience significantly greater metabolic costs when challenged with salinity. How- ever, an observed difference in gill raker length and density is most probably related to the nutritional condition of their habitat, indicating that individuals can rapidly acclimatize to different diets.

\section{Keywords}

osmoregulation, oxygen consumption, salinity, , morphometry 
Most of the work on rapid evolution in three-spined sticklebacks and adaptation to freshwater has focused on northern populations (DeFaveri et al., 2011; Hohenlohe et al., 2010; Mäkinen et al., 2006; Taugbøl et al., 2014) and very few studies have considered southern populations, notably those of the Mediterranean bioclimatic region which constitutes the southern limit of the species range in the west- ern Palearctic (Crivelli and Britton 1987). Furthermore, some of these southern peripheral populationshave steeply declined (Clavero et al., 2009; Foster et al., 2003; Kottelat and Freyhof, 2007). For example, in the Iberian Peninsula, the species is now considered to be endangered following IUCN criteria, after the occurrence of multiple local extinction events from most of its past distribution (Araguas et al., 2012; Clavero et al., 2009; Foster et al., 2003; Reimchen, 1984; Sanz et al., 2015; Vila et al., 2017). Similarly, this species is listed as threatened or endangered in some Neoarctic locations. For example, the unarmoured three-spined stickleback

subspecies Gasterosteus aculeatus williamsoni, located in Southern California, has been on the U.S. Fish and Wildlife Services Endangered Species List since 1970. Other stocks of sticklebacks have also been listed as threatened by states such as Massachusetts and Pennsylvania (Williams et al., 1989). However, along the northern coast of the Mediterranean Sea, stickle- backs living in the Camargue area (Rhone delta) are still abundant (Poizat et al., 2002; Rind et al., 2018). The Camargue is an ecological hotspot of diversity and has been a Biosphere Reserve since 1977. It has an exceptional biological richness and covers 13,000 ha between the northern mesohaline, brackish water Vaccares lagoon and the Mediterranean Sea. It is made up of freshwater ponds and shallow water canals with abundant vegetation, freshwater drainage canals with submerged vegetation, mesohaline (brackish water) and euryha- line (brackish to hypersaline) lagoons flooded throughout the year (Crivelli and Britton 1987).

Since the last ice age ended about 10,000 years ago, sticklebacks have repeatedly colonized freshwater habitats because thousands of new streams and lakes formed during glacial retreats (Bell and Foster, 1994; Schluter, 2000). Therefore, postglacial freshwater stickleback populations share a common suite of adaptation throughout the northern hemisphere such as armour reduction (Bell, 1987; Bell and Foster, 1994; Colosimo et al., 2005). They also differ significantly in morphology due to divergent selective pressures that they experi- ence

in contrasting freshwater habitats (Baumgartner, 1992; Bell, 1982; Reimchen et al., 1985; Spoljaric and Reimchen, 2007). For example, divergent natural selection for the exploitation of benthic vs. limnetic habitats and associated food items is one of the most com-mon diversifying mechanisms affecting resident freshwater stickle- backs (Walker, 1997; Spoljaric and Reimchen, 2007). Sticklebacks also inhabit a large number of coastal brackish water systems throughout the northern hemisphere and present therefore an extremely wide haloniche (Bell and Foster 1994; Wootton, 1976).

Most fish species living in their native freshwater or marine environments are stenohaline and are not able to survive non-native salin- ities. However, for euryhaline fish such as sticklebacks, the osmoregulatory machinery is adapted to a wide range of salinities. These fish can sustain salinity variations of their environment and move or migrate to non-native salinities (Moyle and Cech, 1996). However, osmoregulation mustbe costly to maintain (Perry and Fryer, 1997). This cost is expected to be higher in non-native environ- ments compared to native environments due to local acclimation pro- cesses. For

instance, the expressionof genes related to osmoregulation is considered to be reduced in native environments because of the selection for reduced energy expenditure (Aykanat et al., 2011). Although this physiological plasticity facilitates acclima-tion and the colonization of novel environments (through strong eury- haline capacity), the bioenergetic costs (increased lipid, protein and carbohydrate metabolism) and possible associated physiological trade- offs may, however, lead ultimately to adaptive evolution (Dalziel et al., 2009; Komoroske et al., 2016; Schulte, 2001; Watt, 1985).

The physiological mechanisms involved to maintain ion and water homeostasis are coordinated between the gills, the kidney and the gut (Eddy and Handy, 2012). In fish, the ionocytes, also known as the chloride cells or mitochondria rich cells (MRCs), are crucial cells to facilitate ion transport (Laurent, 1984; Jurss and Bastrop 1995; Rind et al., 2018). The internal structure of these cells is rich in mitochon- dria and also possesses a tubulovesicular system composed of basal membrane invaginations containing the sodium pump, $\mathrm{Na}+/ \mathrm{K}+$

ATPase, or NKA (Evans and Claiborne, 2009; Dymowska et al., 2012). This key enzyme involved in salinity tolerance (Herrera et al., 2009; Sampaio and Bianchini, 2002; Yang et al., 2009) is responsible for the exclusion of three sodium ions from the cell in exchange for two potassium ions, requiring thehydrolysis of one ATP molecule. Its activity maintains cell membrane potential, facilitates ion transport via channels and transporters that are localized in the apical and bas- olateral membranes, and thus maintains osmotic equilibrium and cell volume. NKA is mostly located in gill ionocytes, the intestinal absorb- ing enterocytes and ionocytes found along the tubules of the kidney (Evans and Claiborne, 2009). NKA activity has already been measured in thegills and kidney

of sticklebacks kept at different salinities (Divino et al., 2016; Judd, 2012; Jurss et al., 1982; Schaarschmidt et al., 1999). Also, changes in salinity and the coordinated physiologi- cal response are often reflected by different oxygen consumption rates (Gracia-Lopez et al., 2006; Morgan et al., 1997). This measure- ment can be used as an indicator of fish metabolism (Cech, 1990) and to assess the osmoregulatory cost (da Silva Rocha et al., 2005; Morgan and Iwama, 1998; Tsuzuki et al., 2008). This cost can impact growth rate (Boeuf and Payan, 2001,

Imsland et al., 2003, Woo and Kelly, 1995) with also a minimal osmoregulatory energy demand in an environment that is natural for a particular species, therefore indicat- ing some fitness-related advantages of being adapted to local environ- mental salinities (Morgan and Iwama, 1991).

The aim of this study was to determine whether Mediterranean sticklebacks living in different saline environments (freshwater-low salinity drainage canals and euryhaline-seawaterlagoons) of the Camargue area have different morphological and physiological traits. It

is hypothesized that this coastal population is morphologically homogenous. However, fish sampled from contrasted saline water 
bodies could respond differentially when challenged with abrupt salin- ity transfers. It is predicted that oxygen consumption rates, as a mea- sure of metabolic rate, could reflect the key functional osmoregulatory changes that occur with salinity changes, such as NKA activity modulations. To test these hypotheses, we analysed the morphology of fish sampled directly from the different aquatic envi- ronments, Acclimated sticklebacks were challenged with abrupt salin- ity transfers in controlled experimental conditions to evaluate whether some phenotypic traits could be habitat specific at different physiological levels (gill NKA activity and individual oxygen consumption).

\section{MATERIALS AND METHODS}

\section{1 | Fish sampling and experimental design}

In the Camargue region, a protected area located within the Rhone river delta in Southern France, subadult three-spined sticklebacks (Gasterosteus aculeatus) were fished from 1993 to 2017 and from dif- ferent water bodies (Table 1) using fixed hoop nets of decreasing mesh size from 13 to $6 \mathrm{~mm}$ at the end of the hoop net ("capéchade"). This sampling was carried out to determine how homogenous the population had been over the last 24 years and to determine whether migration and mixing could occur in this coastal wetland area. Immediately after fishing, some of the collected fish were directly fixed in $10 \%$ formalin and kept in alcohol until use. For the physiological study, fish [fresh body weight (FBW) $0.56 \mathrm{~g} \pm 0.18$ ] were collected in December 2016 and February 2017 from three different areas. One sampling site corresponds to a freshwater-low salinity (FW-LS) drain- age canal (Versadou canal, salinity values $<5 \%$ ) running from the Rhône river and loading FW into a brackish (BW)/seawater (SW) lagoon (La Contesse lagoon). The other two sites correspond to the constantly BW Vaccares lagoon (salinity of 20-25\%o) and the BW/SW Marteau lagoon (salinity ranging from 20 to $50 \%$ ). These salinities recorded during fish sampling correspond to the salinities typically measured during that period of the year (winter). However, the highest salinities up to $50 \%$ were only be recorded during the summer period. These sites are partially interconnected, but their topography could limit migration and mixing among sticklebacks living in these contrastedhabitats. $\quad$ Typically, dams, "salt dams" and the numerous locks along the drainage canals and between lagoons could constrain fish dispersal.

Captured fish were directly transported to the laboratory facility at the University of Montpellier, France in separate large oxygenated containers filled with water from the respective sampling sites. Fish were then kept at room temperature $\left(21^{\square} \mathrm{C}\right)$ and under a natural pho- toperiod in separate tanks containing $100 \mathrm{I}$ of recirculated and filtered water (12 fish per tank with an approximate $1: 1$ sex ratio) for an accli- mation period of 2-3 weeks. Fish were then transferred to $40 \mathrm{I}$ tanks and maintained at different salinities for another 2 weeks. Fish from the BW Vaccares lagoon were acclimated to $30 \%$ or $5 \%$, those from the BW/SW Marteau lagoon were kept at $30 \%$ o and those from the FW-LS Versadou canal at $5 \%$. Fish were fed three times a day with chironomid larvae (EXOMARC, Lormont, France), excluding the last day before experimentation. Salinity and temperature levels were recorded using a YSI 30 Conductivity/Salinity/Temperature instru- ment (Yellow Springs, Ohio). Fish behaviour was also checked daily. After this acclimation period, fish were directly used for respirometry measurements, with or without salinity transfers from SW to LS or from LS to SW (Figure 1a-c). For gill sampling, fish were sacrificed with an overdose of anaesthetic (2-phenoxyethanol, $500 \mathrm{mg} \mathrm{l}^{-1}$ ), and then dissected on ice. Gills were either directly frozen in liquid nitro- gen or kept at $-80^{\circ} \mathrm{C}$ for NKA activity measurements.

\subsection{Morphometry}

For bone and lateral plate staining, fish kept in alcohol were stained overnight with $0.008 \%$ Alizarin Red S in $1 \%$ potassium hydroxide, destained in water overnight, then lightly cleared in a $0.25 \%$ potas- sium hydroxide $/ 50 \%$ glycerol solution. The number of lateral plates

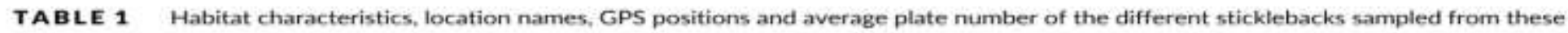
sites

\begin{tabular}{|c|c|c|c|c|c|c|c|c|c|c|}
\hline \multirow[b]{2}{*}{ Habitats } & \multirow[b]{2}{*}{ Location name } & \multirow[b]{2}{*}{ GPS position } & \multirow[b]{2}{*}{1993} & \multicolumn{6}{|c|}{ Mean number of plates/year } & \multirow{2}{*}{$\begin{array}{l}\text { Mean number of } \\
\text { plates } \pm \text { S.E.M. }\end{array}$} \\
\hline & & & & 1994 & 1995 & 1996 & 2001 & $2016 / 17$ & & \\
\hline \multirow{4}{*}{$\begin{array}{c}\text { Freshwater } \\
\text { (drainage } \\
\text { canals) }\end{array}$} & Fumemorte & $43^{\prime} 31^{\prime} 43,2^{\prime} \mathrm{N}$ & $4 \cdot 42^{\prime} 10,9^{\prime} \mathrm{E}$ & & & & & & $4,5 \pm 0.97$ & $4,5 \pm 0.97$ \\
\hline & Baisse salée & $43^{\circ} 29^{\prime} 15,0^{\prime} \mathrm{N}$ & $4^{\prime} 39^{\prime} 02,7^{\prime} \mathrm{E}$ & $4.7 \pm 0.67$ & $4.3 \pm 0.67$ & & $4.7 \pm 0.9$ & & & $4,5 \pm 0,77$ \\
\hline & Giraud & $43^{\prime} 29^{\prime} 28.8^{\prime} \mathrm{N}$ & $4 \cdot 41^{\prime} 42.1^{\prime} \mathrm{E}$ & & & $4.5 \pm 0.73$ & & & & $4.5 \pm 0.73$ \\
\hline & Versadou & $43^{\circ} 27^{\prime} 15,2^{\prime} \mathrm{N}$ & $4^{\prime \prime} 35^{\prime} 22,6^{\prime} \mathrm{E}$ & & & & & & $3,9 \pm 0,73$ & $3,9 \pm 0,73$ \\
\hline \multirow[t]{3}{*}{ Mesohaline } & Vaccares & $43^{*} 32^{\prime} 16,0^{\prime} \mathrm{N}$ & $4^{\prime \prime} 37^{\prime} 54,0^{\prime} E$ & & $4.1 \pm 0.99$ & & $4.3 \pm 1.15$ & & $3.5 \pm 0.52$ & $3,9 \neq 0,96$ \\
\hline & La Capeliêre & $43^{\circ} 32^{\prime} 26,0^{\prime} \mathrm{N}$ & $A^{\prime \prime} 38^{\prime} 33,9^{\prime} \mathrm{E}$ & & & & & $4.4 \pm 0.66$ & & $4,4 \pm 0,66$ \\
\hline & Fournelet & $43^{\circ} 29^{\prime} 37.7^{\prime} \mathrm{N}$ & $4^{\prime} 37^{\prime} 24,9^{\prime} \mathrm{E}$ & & & & $4.8 \neq 0.63$ & & & $4,8 \neq 0.63$ \\
\hline \multirow[t]{2}{*}{ Euryhatine } & Marteau & $43^{\circ} 27^{\prime} 36,4^{\prime} \mathrm{N}$ & $4^{\circ} 34^{\prime} 58,3 / E$ & & & & & & $4.8 \pm 0.63$ & $4,8 \pm 0,63$ \\
\hline & Malagroy & $43^{\prime} 30^{\prime} 41,6^{\prime} \mathrm{N}$ & $4^{\prime} 29^{\prime} 16.6^{\prime} \mathrm{E}$ & & & & $4.7 \pm 0.94$ & & & $4,7=0,94$ \\
\hline
\end{tabular}


were counted from 10 fish collected from the different sampling sites. In addition, head height, body height, dorsal fin length and gill raker length were measuredusing the ImageJ image processing program (National Institute of Health, Bethesda, MD, U.S.A.). For gill rakers, only the first gill from the left branchial arch was consid- ered. Gill raker lengths were measured from the base to the tip of the rakers. Gill raker density was measured as the number of gill rakers positioned along the gill arch along a distance of $100 \mu \mathrm{m}$. The ratio of these values with the fish length was also calculated. Digital images of fish viewed laterally anddissected gills were acquired on a (Leica

DM2500, Germany). Fixed gills were also observed with a

FEI Quanta 200 electron optics international B.V., netherlands using

the conventional mode (high vacuum) and a

Thornley-Everhart secondary electron detector.Prior to SEM observations of the gill rakers, samples were dehydrated, bathed in 1,1,1,3,3,3-hexamethyldisilazane, air-dried, glued to specimen stubs and coated with palladium for $180 \mathrm{~s}(\sim 40 \mathrm{m \AA})$ using an Edwards Sputter Coater (BOC Edwards, UK).

(a)

(a)

\begin{tabular}{|l|l|l|}
\hline Control SW (30\%) & $\begin{array}{c}\text { Oxygen } \\
\text { consumption }\end{array}$ & NKA activity \\
\hline Control SW (30\%) & $24 \& 72 \mathrm{hrs}$ & $0,24 \& 72 \mathrm{hrs}$ \\
\hline Transferred LS (5\%)
\end{tabular}

(b)

\begin{tabular}{|c|c|c|c|}
\hline (1) & & $\begin{array}{c}\text { Oxygen } \\
\text { consumption }\end{array}$ & NKA activity \\
\hline \multirow{2}{*}{ Control SW [5\%a] } & Control LS (5\%) & \multirow{2}{*}{$24 \& 72 \mathrm{hrs}$} & \multirow{2}{*}{$0.24 \& 72$ hrs } \\
\hline & Transferred SW (30\% & & \\
\hline
\end{tabular}

(c)

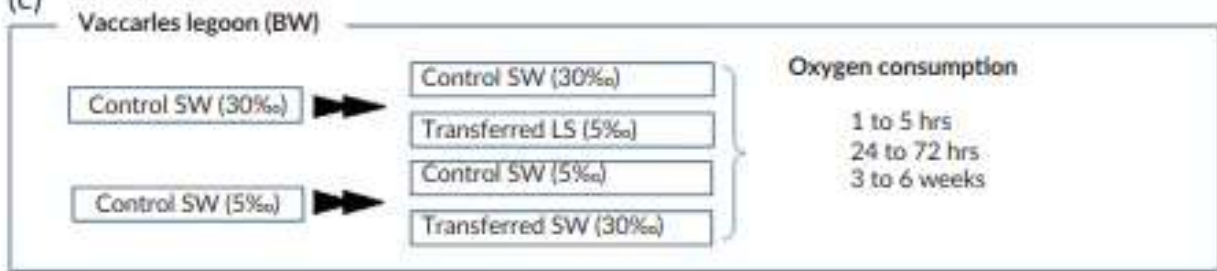

(d)

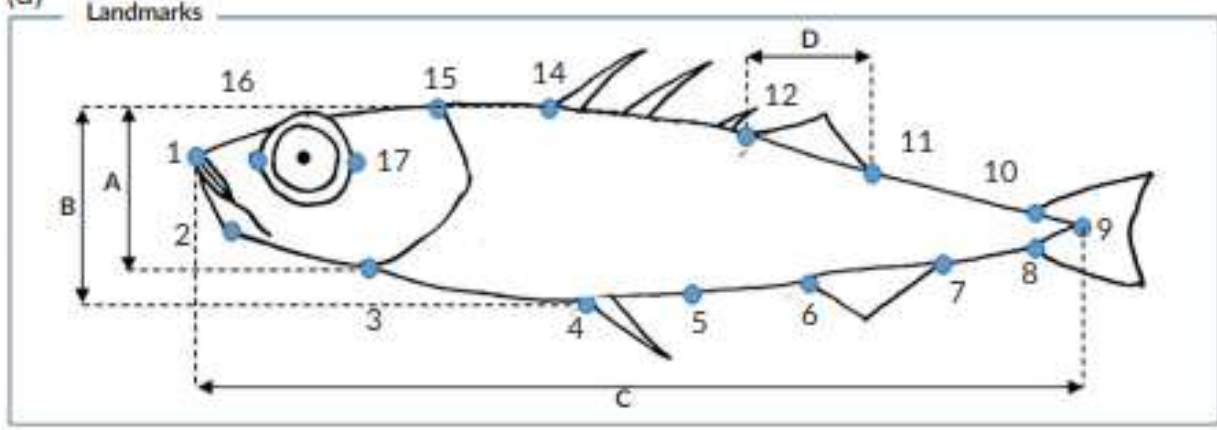

Fish morphology was analysed using landmark-based geometric morphometrics. Seventeen landmarks were digitized on the right side of the body using TpsDIG (Rohlf, 2005) in order to get the $X$ and $Y$ coordinates (Figure 1d). Digitized landmarks were then transferred to MorphoJ (Klingenberg, 2011). Data were analysed through a principal component analysis (PCA) for shape variance, then principal compo- nent coefficient scores were transferred to Excel (2013) to visualize the possible variations between fish sampled from the FW-LS habi- tats and those from the mesohaline-SW lagoons.

\subsection{Oxygen consumption rate}

Respiration measurements were conducted in $73 \mathrm{ml}$ transparent metabolic chambers, equipped with an oxygen optode (OXSP5, sensor code SD7-545-214) (Pyro-Science GmbH, Aachen, Germany) previously glued to its inner wall. Optodes were calibrated to $100 \%$ (using airsaturated water) and $0 \%$ air saturation (using a freshly made 
$80 \mathrm{mM} \mathrm{Na}_{2} \mathrm{SO}_{3}$ solution). Each metabolic chamber was equipped with a magnetic stirrer (to ensure correct $\mathrm{O}_{2} \quad$ mixing in the water column) and partially immersed in a 2 I tank. This tank contained a water pump connected to the metabolic chamber through a hole on the lid of the chamber also allowing water overflow and was supplied with an aera- tion system to maintain water fully oxygenated. A structure of $1 \mathrm{~mm}^{2}$

mesh was installed at the bottom of the chamber above the magnetic stirrer in order to keep the fish away from the stirrer. Fish were intro- duced in each of the chambers containing filtered $(0.2 \mu \mathrm{m}$ Whatman) medium at the salinity values at which the animal was acclimated $24 \mathrm{~h}$ before salinity transfer. After this time, the water of each tank and metabolic chamber was quickly siphoned and replaced with water at the desired salinity.

The rates of oxygen consumption were measured at room temperature $\left(21^{\circ} \mathrm{C}\right)$ and at different salinities (freshwater $0,5 \%$ and sea- water $30 \%$ ). To ensure that fish were consuming $\mathrm{O}_{2}$ differentially at different temperatures, the effects of SW to LS transfers on oxy- gen consumption were analysed at 21 and $23^{\circ} \mathrm{C}$. Similarly, the rate of oxygen consumption was also assessed with LS to SW transfers monitored at $25^{\circ} \mathrm{C}$. Change in oxygen concentration over time within each of the chambers was measured at different times before and after water transfer ( $1 \mathrm{~h}$ before, immediately after transfer, 1, 2, 3, 5, 24, 72 $\mathrm{h}$ after transfer and up to 3 and 6 weeks after salinity transfer) using 20 min periods during which the water pump and aeration system were shut off. Oxygen concentration was measured usinga four-channel fibreoptic oxygen meter (FireSting,Pyro- Science $\mathrm{GmbH}$, Aarhen, Germany) and recorded through Pyro Oxy-gen Logger software (Pyro-Science $\mathrm{GmbH}$, Aarhen, Germany). All measurements started in fully oxygenated water (>98\%) and respira- tion was recorded as a function of declining $\mathrm{pO}_{2}$ over time. Parallel

measurements were carried out at a time (including a blank) and data were recorded using $5 \mathrm{~s}$. intervals. Animals were then weighed

\section{TA B LE 2 Body morphology of sticklebacks sampled from FW-LS and SW habitats}

\begin{tabular}{llllllllll}
$\begin{array}{l}\text { Head height/ } \\
\text { FL (A) }\end{array}$ & $\begin{array}{l}\text { Head length/ } \\
\text { FL }(1-15)\end{array}$ & $\begin{array}{l}\text { Body height// } \\
\text { FL (B) }\end{array}$ & $\begin{array}{l}\text { Eye diameter } \\
(16-17)\end{array}$ & $\begin{array}{l}\text { Pelvic girdle/ } \\
\text { FL (4-5) }\end{array}$ & $\begin{array}{l}\text { Dorsal Fin/ } \\
\text { FL (D) }\end{array}$ & $\begin{array}{l}\text { Jew length/ } \\
F L(1-2)\end{array}$ & $\begin{array}{l}\text { Snout length/ } \\
\text { FL (1-3) }\end{array}$ & $\begin{array}{l}\text { Caudal height } \\
(8-10)\end{array}$ \\
FW-LS & $20,5 \pm 0,50$ & $23,65 \pm 1,65$ & $23 \pm 1,30$ & $10,24 \pm 0,53$ & $9,4 \pm 0,21$ & $23,6 \pm 0,20$ & $6,35 \pm 1,31$ & $3,47 \pm 0,75$ & $9,11 \pm 1,70$ \\
SW & $20,3 \pm 0,60$ & $22,97 \pm 1,48$ & $22,8 \pm 0,90$ & $9,45 \pm 1,05$ & $10,9 \pm 0,20$ & $23,1 \pm 0,28$ & $6,22 \pm 0,83$ & $3,75 \pm 0,63$ & $11,08 \pm 4,12$ \\
\hline
\end{tabular}

Note: Data are presented as ratios of different measures: means \pm S.E.M. $\times 100 /$ fish length (FL). Elements in brackets refer to the landmarks illustrated in Figure 1d. Body parameters were obtained from 10 fish collected from the FW-LS Versadou canal and 12 from the SW Marteau tagoon.

FIGURE 2 First and second principle components of morphological variance between FW-LS and SW sticklebacks. Body parameters were obtained from fish collected from the FW-LS habitats (Baisse Salée and Giraud lagoons, Fumemorte and Versadou canals) and the mesohaline/5W lagoons (Malagroy and Marteau lagoons)

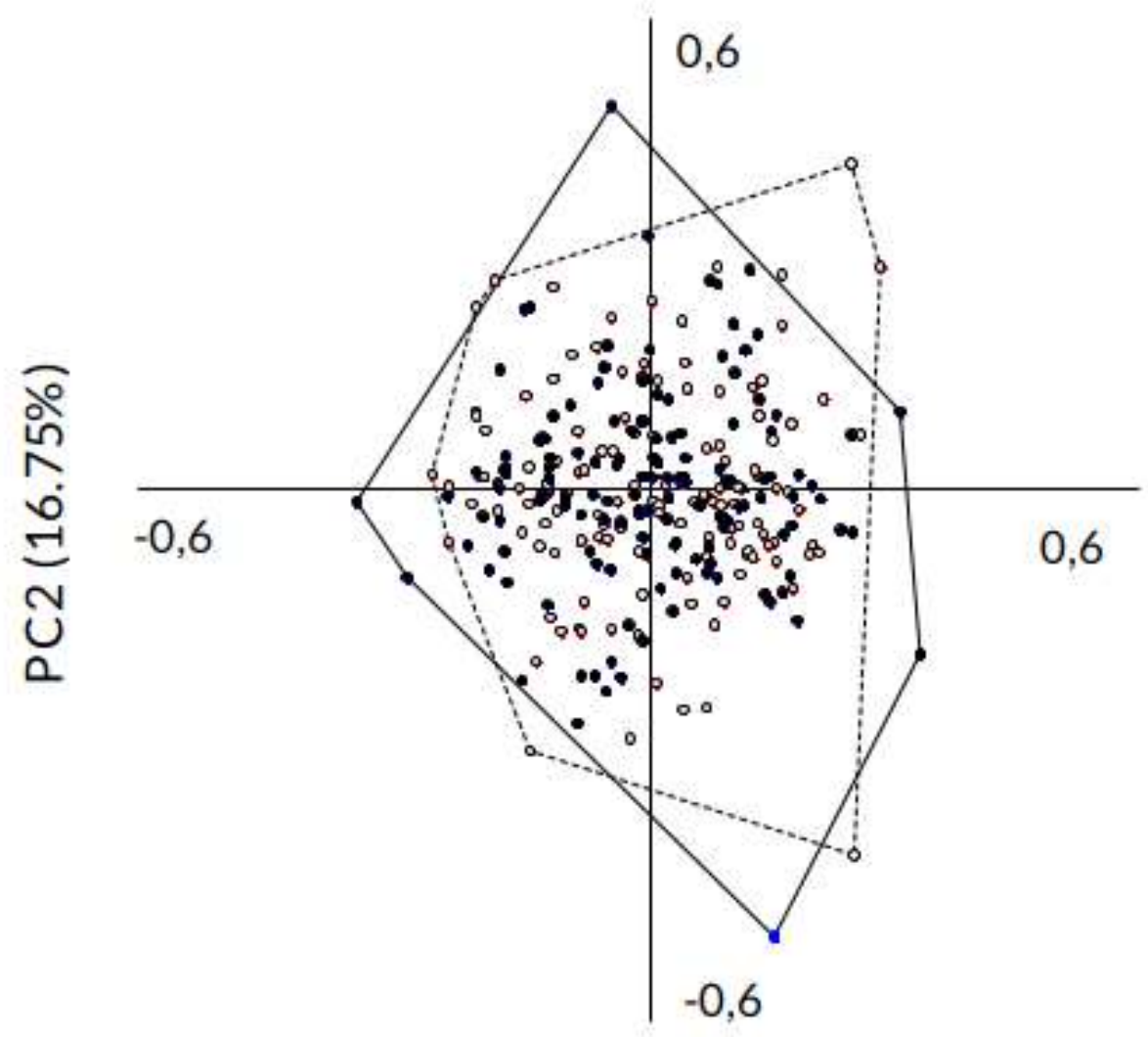

PC1 (32.937\%) 
From each fish, four gill arches (from the same side of the fish) were dissected and homogenized in pairs in sucrose-EDTA-imidazole (SEI) buffer (150 mM sucrose, $10 \mathrm{mM}$ EDTA, $50 \mathrm{mM}$ imidazole, $\mathrm{pH}$ 7.4) using a manual Potter-Elvehjem tissue homogenizer. The specific, $\mathrm{Na}+-$ and $\mathrm{K}+$-dependent, ouabain-sensitive ATPase activity was measured in these homogenates using $1.4 \mathrm{mM}$ of ouabain as described in detail by Metz et al. (2003). Aliquots ( $10 \mu \mathrm{l}$ in triplicate) of homoge- nate (protein content of $1 \mathrm{mg} \mathrm{ml}^{-1}$ ) were incubated in assay medium for $20 \mathrm{~min}$ at $25^{\circ} \mathrm{C}$ in microplate wells. Sample protein content was estimated using the protocol originally described by Bradford (1976) using a commercially prepared reagent (Sigma-Aldrich, St Louis, U.S.A.), and bovine serum albumin as standard. Initially, two different substrate concentrations were checked (dilution at 1:10 and 1:20) Optical densities were recorded using a spectrophotometer (Tecan Infinite M200, Switzerland). Only the linear part of the slopes for the optical densities read at $630 \mathrm{~nm}$ were considered. The specific activity was calculated by subtracting the $\mathrm{K}$-independent, ouabain-insensitive ATPase activity from total ATPase activity. ATP hydrolysis was assessed by the amount of inorganic phosphate formed per minute per milligram of protein.

\subsection{Statistical analysis}

Data normality validation was checked using a Shapiro test. Homoscedasticity was tested by the Bartlett test, and the residual independence was checked with the Durbin-Watson test allowing parametric tests to be used. Results were evaluated by one-way analysis of variance (ANOVA), followed by Dunn's test or Tukey post hoc test (honestly sig-nificant difference) with a significance level of $P<0.05$. t-tests were also performed in order to compare the different ratios. A one-way ANOVA was used to test gill raker data. All statistical analyses were conducted using the $R$ package, IBM SPSS Statistics 23 and Microsoft Excel (2013). All results are presented as means \pm S.E.M.

\section{RESULTS}

\subsection{Fish morphometry}

Sticklebacks fished since 1993 from different aquatic habitats of the
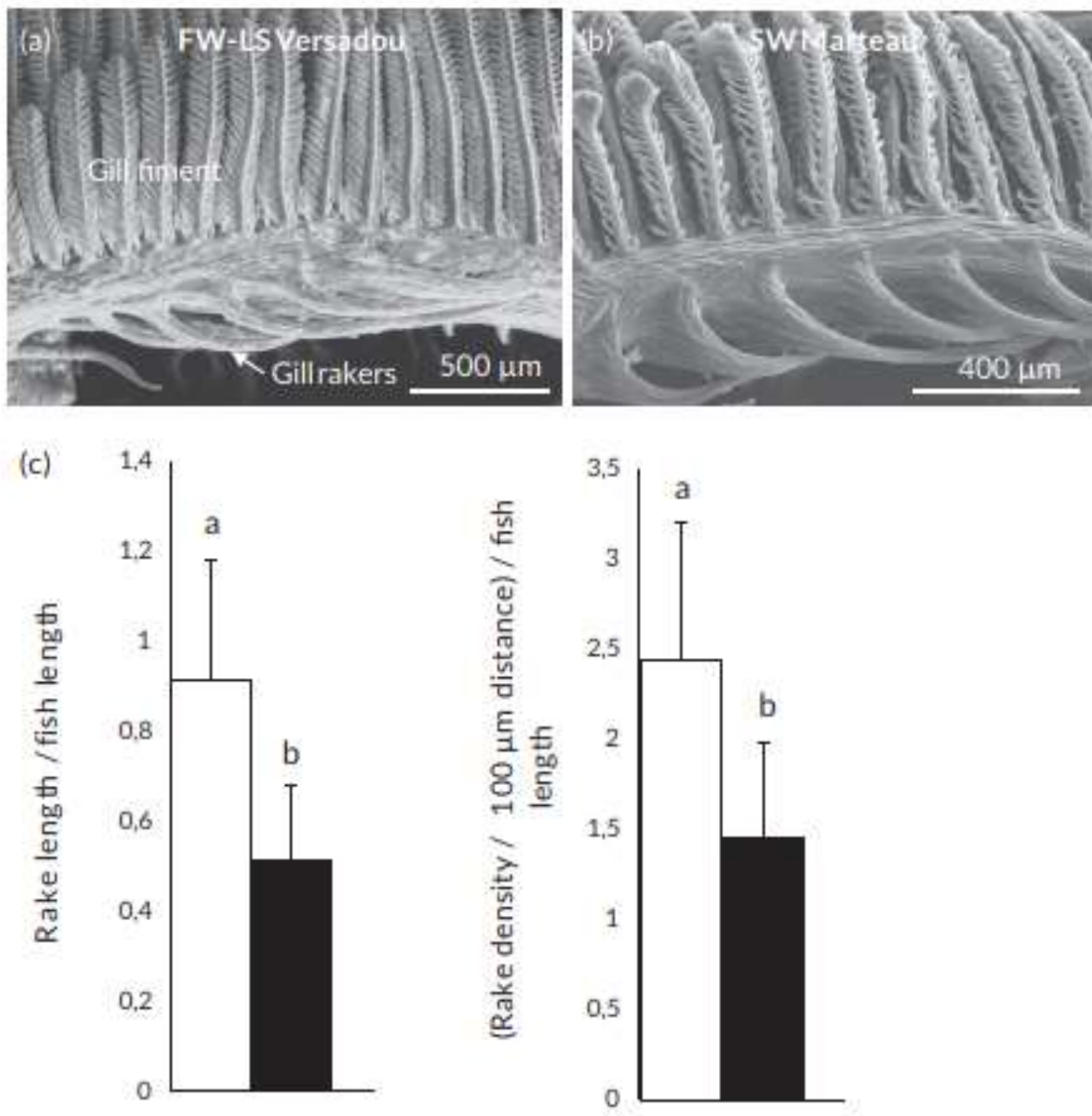

FIGURE 3 Representative SEM images of gill arches from one stickleback collected from the Versadou canal (FW-LS) (a) and one from the Marteau lagoon (SW) (b). Gill raker length according to fish length and gil raker density along $100 \mu \mathrm{m}$ of the gill arch according to fish length for FW-LS (Versadou) and SW (Marteau) sticklebacks (c). Results are presented as means \pm S.E.M. Data were obtained from 10 fish collected from the FW-LS Versadou canal and 12 from the SW Marteau lagoon 
minimum of two and a maximum of six lateral plates observed for some of these fish. No statistical differences in lateral plate number between the different locations and salinities could be identified

(Table 1). Also, no statistical differences were observed in terms of body morphology between sticklebacks sampled in 2016-17

(Vaccares and Marteau lagoons, Fumemorte and Versadou canals) and those sampled since 1993 (Malagroy, La Capelière, Fournelet, Baisse Salée and Giraud lagoons) (Tables 1 and 2).

Morphogeometric analysis using 17 different landmarks from fish sampled from the FW-LS habitats (Baisse Salée and Giraud lagoons, Fumemorte and Versadou canals) and the mesohaline-SW lagoons (Malagroy and Marteau lagoons) revealed that $32.9 \%$ of the variance
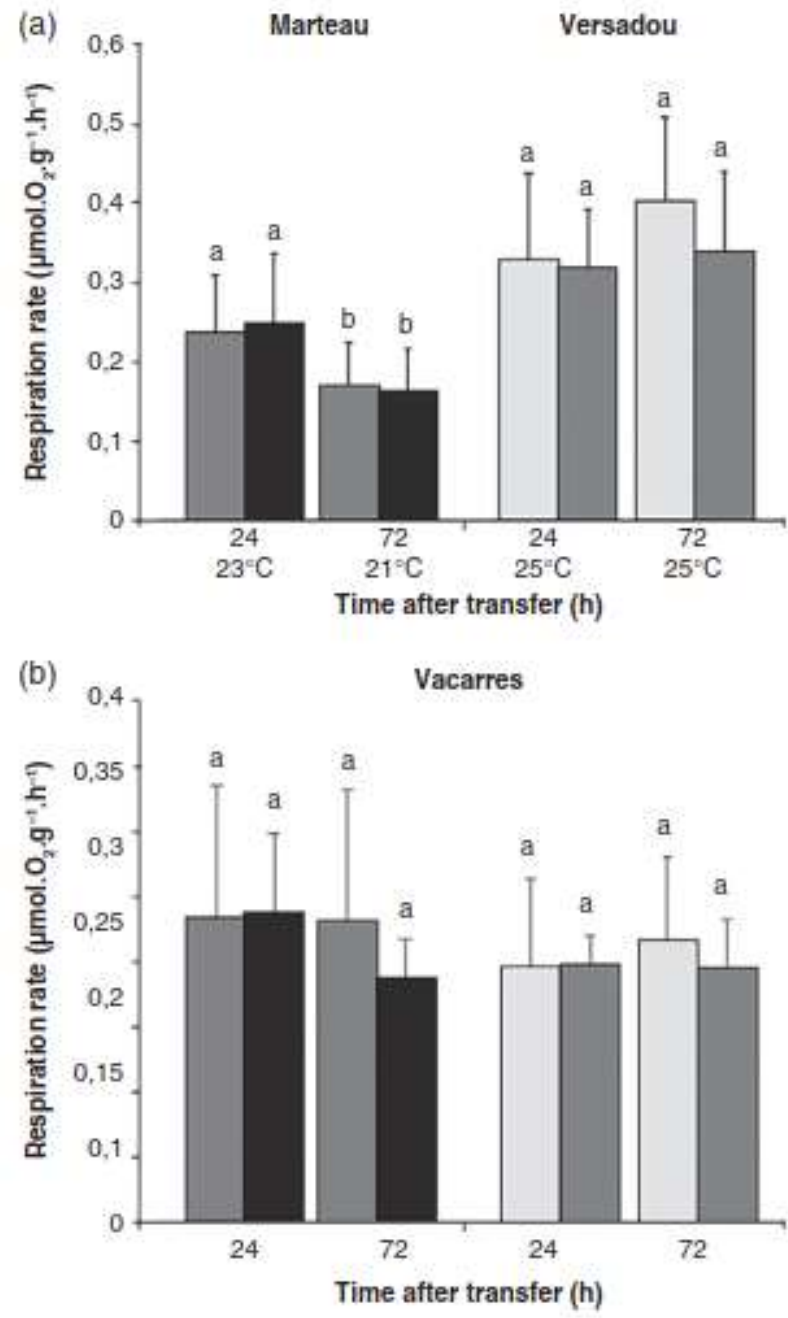

FIGURE 4 (a) Oxygen consumption rate for sticklebacks sampled from the FW-LS Versadou canal (FBW $0.57 \mathrm{~g} \pm 0.18$ ) and the SW Marteau lagoon (FBW $0.54 \mathrm{~g} \pm 0.18$ ). Fish were maintained at different temperatures and transferred 24 and $72 \mathrm{~h}$ after from $S W$ to LS and from LS to SW. (b) Oxygen consumption rates for sticklebacks maintained at $21^{\circ} \mathrm{C}$ collected from the mesohaline Vaccares lagoon (FBW $0.52 \mathrm{~g} \pm 0.13$ ) and maintained in SW or LS and transferred for 24 and $72 \mathrm{~h}$ to LS and SW, respectively. Results are presented as means \pm S.E.M., $10<n<12$ is explained by the first component while the second component accounts for $16.7 \%$ of the variance (Figure 2). The scattered plot for the first and second components indicates limited morphological vari- ations between sticklebacks from the two contrasted habitats. How- ever, a significant difference is observed for the morphology of the gill rakers between sticklebacks sampled from these two habitats

(Figure 3). Gill raker length and gill raker density appeared significantly higher in sticklebacks living in the FW-LS drainage canals compared to the fish living in the mesohaline-SW lagoons.

\subsection{Oxygen consumption rate}

Sticklebacks collected from the FW-LS Versadou canal, the BW Vaccares lagoon and the mesohaline-5W Marteau lagoon, kept at
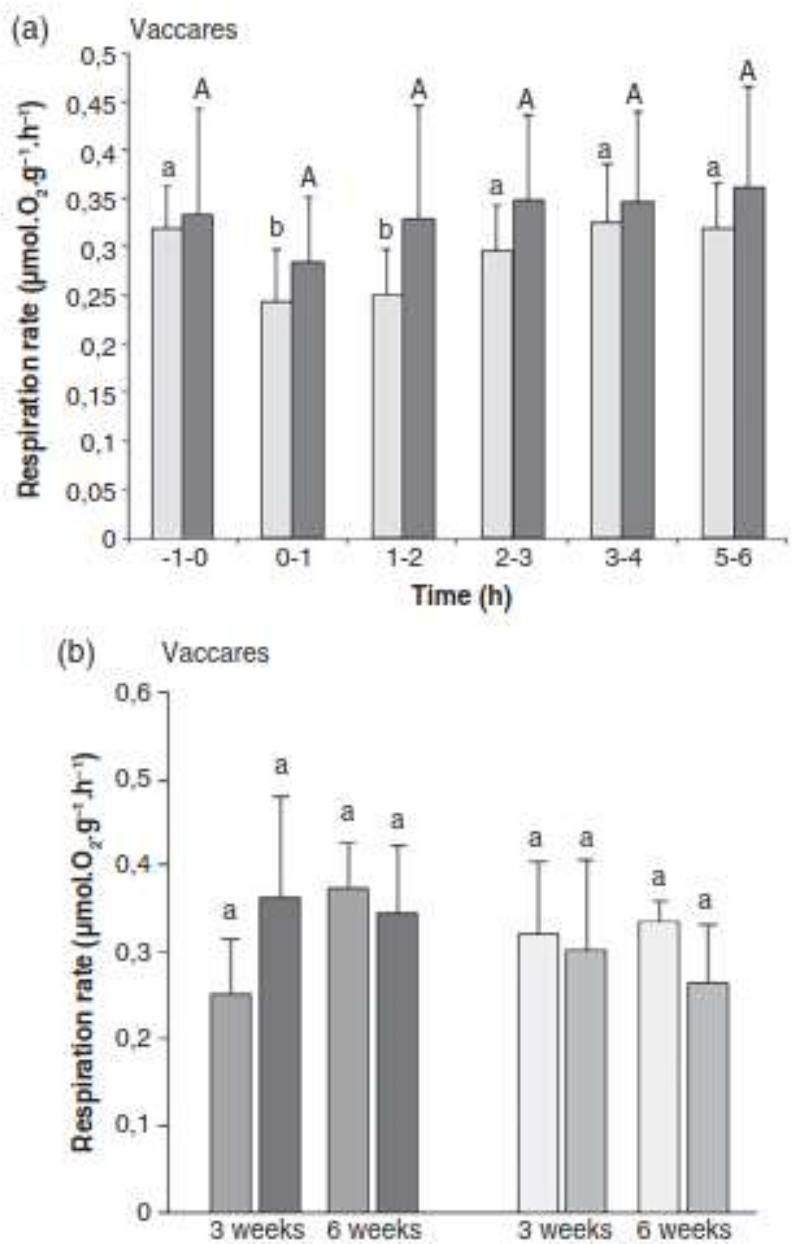

FIGURE 5 Oxygen consumption rate for sticklebacks collected from the mesohaline Vaccares lagoon maintained in SW or LS at $21^{\circ} \mathrm{C}$ and abruptly transferred up to $5 \mathrm{~h}$ to either LS or SW (a). Oxygen consumption rate for sticklebacks from the Vaccares lagoon maintained in SW or LS at $21^{\circ} \mathrm{C}$ and transferred to LS and SW, respectively for 3 and 6 weeks (b). Results are presented as means \pm S.E.M. (a) $6<n<8$, (b) $10<n<12$, FBW $0.52 \mathrm{~g} \pm 0.13$ 
different temperatures $\left(21,23\right.$ and $\left.25^{\circ} \mathrm{C}\right)$ in LS or SW and after salin- ity transfers presented significantly different oxygen consumption rates $(P$ value $=0.0104$ ) (Fig. 4). Oxygen consumption increases with temperature. However, salinity transfer from LS to SW or SW to LSdid not induce any change in the rate of oxygen consumption when recorded 24 and $72 \mathrm{~h}$ after transfer ( $\mathrm{P}$ value $=0.283$ ) (Figure 4a,b).

Sticklebacks collected from the BW Vacarres lagoon and kept in SW presented a significant reduction in oxygen consumption rate immediately and up to $1 \mathrm{~h}$ after abrupt transfer to LS (Figure 5a). However, fish collected from the same environment and kept in LSprior to SW transfer did not modify their oxygen consumption rate during this $6 \mathrm{~h}$ experiment.

A longer acclimation to SW or LS of up to 3 and 6 weeks did not induce any change in oxygen consumption rate compared to fish kept in LS and SW (Figure 5b).

\subsection{Branchial $\mathrm{Na}+\mathrm{K}^{+-A T P a s e}$ activity}

Following direct transfer from SW to LS, branchial Na + K + -ATPase activity of sticklebacks sampled from the SW Marteau lagoon signifi- cantly increased by $28 \%$ and $40 \%$ within 24 and 48 h post transfer, respectively $(P$ value $=0.0009)$ (Figure 6). However, when sticklebacks sampled from the LS Versadou canal were transferred from LS to SW, gill Na+/K+-ATPase activity was significantly decreased by $36 \%$ within $24 \mathrm{~h}(\mathrm{P}$ value $=0.0127)$, resulting in a 1.65 -fold change in gill $\mathrm{Na}+\mathrm{K}+-$

ATPase activity when fish were abruptly transferred to a different salinity. Furthermore, gill $\mathrm{Na} / \mathrm{K}_{+-}$ATPase activity of fish acclimated or

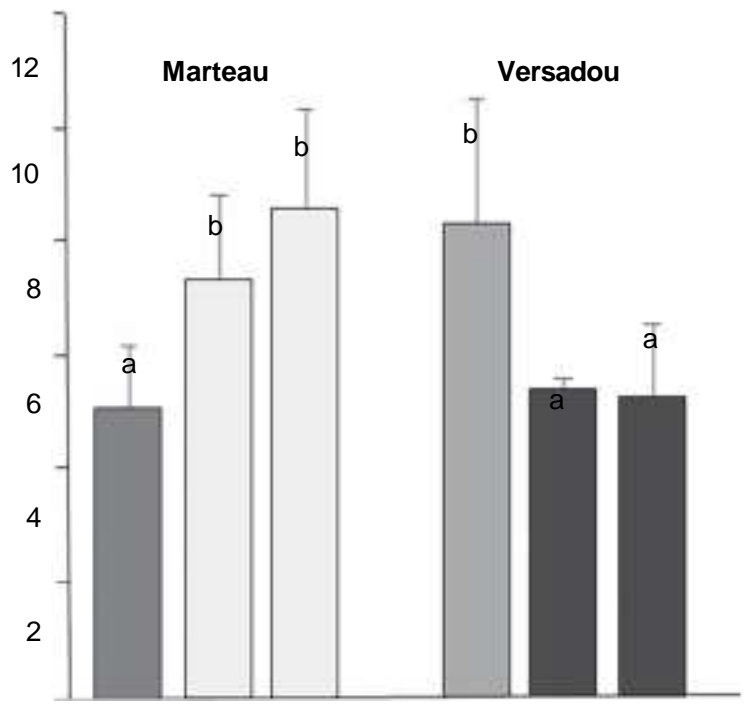

0

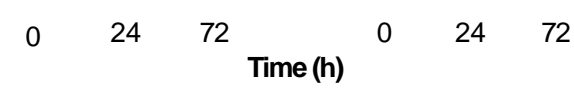

FIGURE 6 Branchial Nat/K+-ATPase activity for fish collected from the SW Marteau lagoon (FBW $0.54 \mathrm{~g} \pm 0.18$ ) and the FW-LS Versadou canal (FBW $0.57 \mathrm{~g} \pm 0.18$ ) maintained at $21^{\circ} \mathrm{C}$ and transferred for 24 and $72 \mathrm{~h}$ from SW to LS and from LS to SW. Results are presented as means \pm S.E.M., $10<\mathrm{n}<12$ transferred to SW or LS appeared to be similar despite the fact that these fish originated from two contrasting habitats.

\section{DISCUSSION}

Three-spined sticklebacks of the Camargue area living within the Rhone river delta in SW, BW or LS-FW habitats have similar body morphologies. Habitat and salinity have no effect on the number of lateral plates. This is consistent with what has already been observed for other southern peripheralpopulations: freshwater and coastal sticklebacks of the Mediterranean bioclimatic region are all lowplated, with fewer than five plates or indeed none at all (Münzing, 1963). Lateral plate number is genetically determined, with a high heritability across all the different morphs, although there can be substantial within-morph variation (Hansson et al., 2016). Usually, marine sticklebacks are predominantly fully plated with more than 30 plates while freshwater fish have fewer than 15 plates, typically between six and 10 (Bell and Foster, 1994; Hansson et al., 2016; Wiig et al., 2016; Østbye et al., 2018). The three-spined stickleback is well known for having undergone adaptive radiation following the end of the last gla- ciation and is well adapted to the freshwater environment (Bell and Foster, 1994). FW populations are less armoured and smaller than the marine ancestral

populations. These typical morphological traits are due to parallel genetic adaptations to a novel environment (Schluter, 1996; Foster and Baker, 2004; Colosimo et al., 2005). Many potential selective agents have been proposed to explain the morphological parallel evolutionary changes across stickleback populations (MacColl and Aucott, 2014; Smith et al., 2014; Spence et al., 2013; Voje et al., 2013). It has been suggested, for example, that the nature and intensity of predation (Hagen and Gilbertson 1973; Reimchen

1980; Bell et al. 1993), buoyancy (Myhre and Klepaker 2009), salinity and calcium availability (Giles 1983; Spence et al., 2012, 2013) can act as selective factors in plate morph evolution for sticklebacks.

Consequently, fitness advantages couldbe related to differences in predator regimes or intensity between different habitats (Reimchen, 1983, 2000). A salinity effect on body shape has also been demonstrated (McCairns and Bernatchez, 2012). However,these authors tracked morphological changes exclusively via partial wrap scores but not in terms of physical shape differences, making their results difficult to interpret (Mazzarella et al., 2015). Also, sticklebacks of the Camargue area have specific life history traits compared to northern populations. They have a shorter life expectancy (1-2 years), a high growth rate, early sexual maturity and a long reproduction period (May to November), reflecting a high metabolism (Crivelli and Britton, 1987). A summer pause in somatic growth has also been

detected in sticklebacks living in intermittent Mediterranean streams (Clavero et al., 2009). This highlights harsh environmental conditions for these Mediterranean fish with an annual life cycle compared to those living further north.

Although collected from contrasted saline environments, stickle- backs of the Camargue area may still have the possibility to migrate locally between these different coastal habitats, especially between 
published (Jurss et al., 1982; Judd, 2012), hypo-osmoregulating fish in SW typically relying on less and smaller ionocytes compared to hyperosmoregulating fish in LS or FW conditions. An increased gill NKA activity has been documented when LS sticklebacks are transferred to SW (Schaarschmidt et al., 1999). In their experiment, fish were trans- ferred to a higher salinity level $(35 \%)$ compared to the one tested in this study $(30 \%)$. As already observed in fish such as the European seabass and the marbled spinefoot, Siganus rivulatus, NKA activity over a large salinity gradient typically presents a $U$ shape curve with maximal activity levels at extreme salinities (Lasserre, 1971; Saoud et al., 2007). Therefore, the hypersaline condition used in the study from Schaarschmidt et al. (1999) could explain the elevated NKA activity they measured.

In conclusion, the low-plated stickleback population sampled from euryhaline, mesohaline and freshwater habitats in the Mediterranean Camargue area are morphologically and physiologically homogenous with efficient osmoregulatory capacities that do not impair their overall energetic

balance. However, some habitat-related differenceswere observed, especially at the gill level. It would be interesting to better characterize the energetic cost of this functional remodelling along the gills

and to identify how individual fish can cope with differential, organ-specific energy use and maintain an overall low energy use. Also, it is known that peripheral populations of wide-ranging species have less genetic variation compared to core populations (Lesica and Allendorf, 1995). Isolated populations that inhabit marginal environ-ments tend to be more geneticallydifferentiated from central populations than isolated populations that do not live in extreme environments (Bouza et al., 1999). Furthermore, local extinction events recently occurred for sticklebacks living at the southern edges of the species distribution (Foster et al., 2003) and particularly in freshwater habitats of Mediterranean climate areas in Europe (Clavero et al., 2009; Kottelat and Freyhof, 2007; Vila et al., 2017). Therefore, there is astrong need for further analysis of the salinity-induced physiological adjustments of these southern peripheral stickleback populations. This could shed light on specific physiological traits and trade-offs limitingthe overall energy use despite a highly demanding environment. This knowledge could efficiently contribute to a better protection of these populations and conserve their evolutionary heritage.

\section{ACKNOWLEDGEMENTS}

We are thankful to the Tour du Valat Research Center for continuous support and for providing adult fish from the Camargue region. Legal authorizations for fish sampling were given to the Tour du Valat Research Center from the local French administration (PACA County,

Direction Interregionalede la Mer Méditerranée, Service Réglementation et Contrôle no. 892 for 2016 and 703 for 2017). We are also grateful to David McKenzie for valuable help during the oxygen consumption measurements and to Shaheed Benazir Bhutto Univer- sity for providing a PhD scholarship for K. Rind. The authors also sin- cerely thank Munro Language Services for correcting the manuscript.

\section{CONFLICT OF INTEREST}

The authors declare that they do not have a conflict of interest.
COMPLIANCE WITH ETHICAL STANDARDS

This study was funded by the Ministère de l'Enseignement Supérieur de la Recherche et de l'Innovation. 
Araguas, R. M., Vidal, O., Pla, C., \& Sanz, N. (2012). High genetic diversity

of the endangered lberian three-spined stickleback (Gasterosteus aculeatus) at the Mediterranean edge of its range. Freshwater Biology,57(1), 143-154.

Aykanat, T., Thrower, F. P., \& Heath, D. D. (2011). Rapid evolution of osmoregulatory function by modification of gene transcription in steelhead trout. Genetica, 139(2), 233242.

Baumgartner, J. V. (1992). Spatial variation of morphology in a freshwater population of the threespine stickleback, Gasterosteus aculeatus. Cana- dian Journal of Zoology, 70(6), $1140-1148$.

Bell, M. A. (1982). Differentiation of adjacent stream populations of threespine sticklebacks. Evolution, 36, 189-199.

Bell, M. A. (1987). Interacting evolutionary constraints in pelvic reduction of threespine sticklebacks, Gasterosteus aculeatus (Pisces, Gas- terosteidae). Biological Journal of the Linnean Society, 31(4), 347-382.

Bell, M. A., \& Andrews, C. A. (1997). Evolutionary consequences of post- glacial colonization of fresh water by primitively anadromous fishes. In Evolutionary ecology of freshwater animals (pp. 323-363). Basel, Swit- zerland: Birkhäuser.

Bell MA, Ortı G, Walker JA, Koenings JP. (1993). Evolution of pelvic reduc- tion inthreespine stickleback fish: a test of competing hypotheses. Evo- lution, 47 : $906-914$.

Bell, M. A., \& Foster, S. A. (1994). The evolutionary biology of the threespine stickleback. New York: Oxford University Press.

Berner, D., Stutz, W. E., \& Bolnick, D. I. (2010). Foraging trait (co) variances in stickleback evolve deterministically and do not predict trajectories of adaptive diversification. Evolution, 64(8), 2265-2277.

Blondeau-Bidet, E., Bossus, M., Maugars, G., Farcy, E., Lignot, J.H. \& Lorin- Nebel, C. (2016). Molecular characterization and expression of Na+/K +-ATPasea1 isoforms in the European sea bass Dicentrarchus labrax osmoregulatorytissues following salinity transfer. Fish Physiol. Bio- chem., 42(6), 1647-1664.

Boeuf, G., \& Payan, P. (2001). How should salinity influence fish growth? Comparative Biochemistry and Physiology Part C: Toxicology \& Pharma- cology, $130(4), 411-423$.

Bolnick, D. I., Caldera, E. J., \& Matthews, B. (2008). Evidence for asymmet- ric migration load in a pair of ecologically divergent stickleback populations. Biological Journal of the Linnean Society, 94(2), 273-287.

Bouza, C., Arias, J., Castro, J., Sánchez, L., \& Martínez, P. (1999). Genetic structure of brown trout, Salmo trutta L., at the southern limit of the distribution range of the anadromous form. Molecular Ecology, 8(12), 1991-2001.

Bradford, M. M. (1976). A rapid and sensitive method for the quantitation of microgram quantities of protein using the principle of protein dye binding. Analytical Biochemistry, 72, 248-254.

Cech, J. J. (1990). Respirometry. In C. B. Schreck \& P. B. Moyle (Eds.), Methods for fish biology. Bethesda, MD: American Fisheries Society

Clavero, M., Pou-Rovira, Q., \& Zamora, L. (2009). Biology and habitat use of three-spined stickleback (Gasterosteus aculeatus) in intermittent Mediterranean streams. Ecology of Freshwater Fish, 18, 550-559.

Crivelli, A. J., \& Britton, H. (1987). Life history adaptations of Gasterosteus aculeatus in a Mediterranean wetland. Environmental Biology of Fishes, 18(2), 109-125.

Colosimo, P. F., Hosemann, K. E., Balabhadra, S., Villarreal, G., Dickson, M., Grimwood, J., \& Kingsley, D. M. (2005). Widespread parallel evolution in sticklebacks by repeated fixation of ectodysplasin alleles. Science,307(5717), 1928-1933.

Costalago, D., Garrido, S., \& Palomera, I. (2015). Comparison of the feeding apparatus and diet of European sardines Sardina pilchardus of Atlantic and Mediterranean waters: Ecological implications. Journal of Fish Biol- ogy, 86(4), 1348-1362.

da Silva Rocha, A. J., Gomes, V., Van Ngan, P., Rocha, M. J. D. A. C., \& Furia, R. R. (2005). Metabolic demand and growth of juveniles of Cen- tropomus parallelus as function of salinity. Journal of Experimental Marine Biology and Ecology, 316(2), 157-165.

Dalziel, A. C., Rogers, S. M., \& Schulte, P. M. (2009). Linking genotypes to phenotypes and fitness: how mechanistic biology can inform molecular ecology. Molecular Ecology, 18(24), 4997-5017.

DeFaveri, J., Shikano, T., Shimada, Y., Goto, A., \& Merilä, J. (2011). Global analysis of genes involved in freshwater adaptation in threespine stick- lebacks (Gasterosteus aculeatus). Evolution, 65(6), 1800-1807.

Divino, J. N., Monette, M. Y., McCormick, S. D., Yancey, P. H., Flannery, K. G., Bell, M. A., ... Schultz, E. T. (2016). Osmoregulatory physiology and rapid evolution of salinity tolerance in threespine stick- leback recently introduced to fresh water. Evolutionary Ecology Research, 17(2), 179-201.

Dymowska, A. K., Hwang, P. P., \& Goss, G. G. (2012). Structure and func- tion of ionocytes in the freshwater fish gill. Respiratory Physiology \& Neurobiology, 184(3), 282292.

Eddy, F. B., \& Handy, R. D. (2012). Ecological and environmental physiology of fishes. Oxford, UK: Oxford University Press.

Evans, D. H., \& Claiborne, J. B. (2009). Osmotic and ionic regulation in fishes. In D. H. Evans (Ed.), Osmotic and ionic regulation: Cells and ani- mals (pp. 295-366). Boca Raton, FL: Taylor and Francis Group.

Foster, S. A., \& Baker, J. A. (2004). Evolution in parallel: New insights from a classic system. Trends in Ecology \& Evolution, 19(9), 456-459.

Foster, S. A., Baker, J. A., \& Bell, M. A. (2003). The case for conserving threespine stickleback populations: protecting an adaptive radiation. Fisheries, 28(5), 10-18.

Giles N. (1983). The possible role of environmental calcium levels during the evolution of phenotypic diversity in Outer Hebridean populations of the three-spined stickleback, Gasterosteus aculeatus. Journal of Zoology, 199: 535-544.

Gow, J. L., Peichel, C. L., \& Taylor, E. B. (2007). Ecological selection against hybrids in natural populations of sympatric threespine sticklebacks. Journal of Evolutionary Biology, 20(6), 2173-2180.

Gracia-Lopez, V., Rosas-Vazquez, C., \& Brito-Perez, R. (2006). Effects of salinity on physiological conditions in juvenile common snook Cen- tropomus undecimalis. Comparative Biochemistry and Physiology Part A: Molecular \& Integrative Physiology, 145(3), 340-345.

Gross, H. P., \& Anderson, J. M. (1984). Geographic variation in the gillrakers and diet of European threespine sticklebacks, Gasterosteus aculeatus. Copeia, 1, 87-97.

Grøtan, K., Østbye, K., Taugbøl, A., \& Vøllestad, L. A. (2012). No short-term effect of salinity on oxygen consumption in threespine stickleback (Gasterosteus aculeatus) from fresh, brackish, and salt water. Canadian Journal of Zoology, 90(12), 1386-1393.

Hansson, T. H., Fischer, B., Mazzarella, A. B., Voje, K. L., \& Vøllestad, L. A. (2016). Lateral plate number in low-plated threespine stickleback: A study of plasticity and heritability. Ecology and Evolution, 6(10), 3154-3160.

Herrera, M., Vargas-Chacoff, L., Hachero, I., Ruíz-Jarabo, I., Rodiles, A., Navas, J. I., \& Mancera, J. M. (2009). Osmoregulatory changes in wedge sole (Dicologoglossa cuneata Moreau, 1881) after acclimation to different environmental salinities. Aquaculture Research, 40(7), 762-771.

Hohenlohe, P. A., Bassham, S., Etter, P. D., Stiffler, N., Johnson, E. A., \& Cresko, W. A. (2010). Population genomics of parallel adaptation in threespine stickleback using sequenced RAD tags. PLoS Genetics, 6(2), e1000862. 
Imsland, A. K., Gunnarsson, S., Foss, A., \& Stefansson, S. O. (2003). Gill Na +, K+-ATPase activity, plasma chloride and osmolality in juvenile tur- bot (Scophthalmus maximus) reared at different temperatures and salin- ities. Aquaculture, 218(1), 671-683.

Judd S, (2012). Na+/K+-ATPase isoform regulation in three-spine stickleback (Gasterosteus aculeatus) during salinity acclimation (Masters degree the- sis). DePaul University, Chicago, IL.

Jurss, K., \& Bastrop, R. (1995). The function of mitochondria-rich cells (chloride cells) in teleost gills. Reviews in Fish Biology and Fisheries, 5,235-255.

Jurss, K., Bittorf, T., Vokler, T., \& Wacke, R. (1982). Experimental studies on biochemical and physiological differences between the three mor-phs of the 3-spined stickleback, Gasterosteus aculeatus L.1. Gill Na/K-ATPase, muscle alanine aminotransferase and muscle aspartate-aminotransferase

activities. Zoologische Jahrbücher. Abteilung für Systematik, Geographie und Biologie der Tiere, 86(2), 267-272.

Kottelat, M., \& Freyhof, J. (2007). In Waterman (Ed.), Handbook of European freshwater fishes (p. 646). Switzerland: Author.

Kim, W. S., Kim, J. M., Kim, M. S., Park, C. W., Huh, H. T. (1998). Effects of sudden changes in salinity onendogenous rhythms of the spotted sea bass Lateolabraxsp. Marine Biology, 131: 219-225.

Kitano, J., Lema, S. C., Luckenbach, J. A., Mori, S., Kawagishi, Y., Kusakabe, M., ... Peichel, C. L. (2010). Adaptive divergence in the thy- roid hormone signaling pathway in the stickleback radiation. Current Biology, 20, 2124-2130.

Klingenberg, C. P. (2011). MorphoJ: an integrated software package for geo- metric morphometrics. Molecular Ecology Resources, 11(2), 353-357.

Komoroske, L. M., Jeffries, K. M., Connon, R. E., Dexter, J., Hasenbein, M., Verhille, C., \& Fangue, N. A. (2016). Sublethal salinity stress contrib- utes to habitat limitation in an endangered estuarine fish. Evolutionary Applications, 9(8), 963-981.

Larson, G. L. (1976). Social behavior and feeding ability of two phenotypes of Gasterosteus aculeatus in relation to their spatial and trophic segre- gation in a temperate lake. Canadian Journal of Zoology, 54(2), 107-121.

Lasserre, P. (1971). Increase of ( $\mathrm{Na}+$ plus $\mathrm{K}+$ )-dependant ATPase activity in gills and kidneys of two euryhaline marine teleosts, Crenimugil labrosus (Risso, 1826) and Dicentrachus labrax (Linnaeus, 1758), during adaptation to fresh water. Life Sciences, II 10, 113-119.

Laurent, P. (1984). Gill internal morphology. In W. S. Hoar \& D. J. Randall (Eds.), Fish physiology (Vol. 10A, pp. 73-184). New York, NY: Academic Press.

Lesica, P., \& Allendorf, F. W. (1995). When are peripheral populations valu- able for conservation? Conservation Biology, 9, 753-760.

MacColl, A. D., \& Aucott, B. (2014). Inappropriate analysis does not reveal the ecological causes of evolution of stickleback Armour: a critique of Spence et al. 2013. Ecology and Evolution, 4(18), 3509-3513.

Matthews, B., Marchinko, K. B., Bolnick, D. I., \& Mazumder, A. (2010). Spe- cialization of trophic position and habitat use by sticklebacks in an adaptive radiation. Ecology, 91(4), 1025-1034.

Mäkinen, H.S., Cano, J. M., \& Merilä, J. (2006). Genetic relationships among marine and freshwater populations of the European three- spined stickleback (Gasterosteus aculeatus) revealed by microsatellites. Molecular Ecology, 15(6), 1519-1534.

Mazzarella, A. B., Voje, K. L., Hansson, T. H., Taugbøl, A., \& Fischer, B. (2015). Strong and parallel salinity-induced phenotypic plasticity in one generation of threespine stickleback. Journal of Evolutionary Biol- ogy, 28(3), 667-677.

McCairns, R. J. S., \& Bernatchez, L. (2012). Plasticity and heritability of morphological variation within and between parapatric stickleback demes. Journal of Evolutionary Biology, 25(6), 1097-1112.

Metz, J. R., van den Burg, E. H., Wendelaar-Bonga, S. E., \& Flik, G. (2003). Regulation of branchial Na+/K+-ATPase in common carp Cyprinus car- pio acclimated to different temperatures. Journal of Experimental Biol- ogy, 206, 2273-2280.

Morgan, J. D., \& Iwama, G. K. (1991). Effects of salinity on growth, metab- olism, and ion regulation in juvenile rainbow and steelheadtrout (Oncorhynchus mykiss) and fall Chinook salmon (Oncorhynchus tshawytscha). Canadian Journal of Fisheries and

Aquatic Sciences, 48(11), 2083-2094.

Morgan, J. D., \& Iwama, G. K. (1998). Salinity effects on oxygen consump- tion, gill Na+, K+-ATPase and ion regulation in juvenile coho salmon. Journal of Fish Biology, 53(5), $1110-1119$.

Morgan, J. D., Sakamoto, T., Grau, E. G., \& Iwama, G. K. (1997). Physiologi- cal and respiratory responses of the Mozambique tilapia (Oreochromis mossambicus)

salinity acclimation. Comparative Biochemistry and Physiology Part A: Physiology, 117(3), 391-398.

Moyle, P. B., \& Cech, J. J. (1996). Fishes. An introduction to ichthyology (3rd ed.). Upper Saddle River, NJ: Prentice-Hall, Inc.

Myhre F, Klepaker T (2009). Body armour and lateral-plate reduction in freshwater three-spinedstickleback Gasterosteus aculeatus: adapta- tions to a different buoyancy regime? Journal of Fish Biology, 75(8): 2062-74.

Østbye K, Taugbøl A, Ravinet M, Harrod C, Pettersen RA, Bernatchez L, VØllestad LA. (2018). Ongoing niche differentiation under high gene flow

in

a polymorphic brackishwater threespine stickleback (Gasterosteus aculeatus) population. BMC Evol Biol. 18(1): 14.

Perry, S. F., \& Fryer, J. N. (1997). Proton pumps in the fish gill and kidney. Fish Physiology and Biochemistry, 17(1), 363-369.

Poizat, G., Rosecchi, E., \& Crivelli, A. J. (2002). Life-history variation within a three-spined stickleback population in the Camargue. Journal of Fish Biology, 60(5), $1296-1307$.

Reimchen TE. (1980). Spine deficiency and polymorphism in a population of Gasterosteus aculeatus: an adaptation to predators? Journal of Zool- ogy, 58: $1232-1244$.

Reimchen, T. E. (1983). Structural relationships between spines and lateral plates in threespine stickleback (Gasterosteus aculeatus). Evolution, 37 (5), $931-946$.

Reimchen, T. E. (1984). Status of unarmoured and spine-deficient populations (Charlotte unarmoured stickleback) of threespine stickle- back, Gasterosteus sp., on the queen Charlotte Islands, British Colum- bia. Canadian Field-Naturalist, 98(1), 120-126.

Reimchen, T. E. (2000). Predator handling failures of lateral plate morphs in Gasterosteus aculeatus: functional implications for the ancestral plate condition. Behaviour, 137(7), $1081-1096$.

Reimchen, T. E., Stinson, E. M., \& Nelson, J. S. (1985). Multivariate differ- entiation of parapatric and allopatric populations of threespine stickle- back in the

Sangan River watershed, Queen Charlotte Islands. Canadian Journal of Zoology, 63(12), 2944-2951.

Rey, T., Lefevre, D., \& Vella, C. (2009). Deltaic plain development and envi- ronmental changes in the Petite Camargue, Rhone Delta, France, in the past 2000 years. Quaternary Research, 71, 284-294.

Rind, K., Beyrend, D., Blondeau-Bidet, E., Charmantier, G., Cucchi, P., \& Lignot, J. H. (2018). Effects of different salinities on the osmoregula- tory capacity of Mediterranean sticklebacks living in freshwater. Jour- nal of Zoology, 303(4), 270-280.

Rohlf, F.J. (2005). Morphometrics at SUNY Stony Brook. Retrieved from http://life.bio.sunysb.edu/morph.

Sampaio, L. A., \& Bianchini, A. (2002). Salinity effects on osmoregulation and growth of the euryhaline flounder Paralichthys orbignyanus. Journal of Experimental Marine Biology and Ecology, 269(2), 187-196.

Sangiao-Alvarellos, S., Laiz-Carrión, R., Guzmán, J. M., del Río, M. P. M., Miguez, J. M., Mancera, J. M., \& Soengas, J. L. (2003). Acclimation of S. aurata to various salinities alters energy metabolism of osmoregulatory and nonosmoregulatory organs. American Journal of Physiology-Regula- tory, Integrative and Comparative Physiology, $285(4)$, R897-R907.

Sanz, N., Araguas, R. M., Vidal, O., \& Viñas, J. (2015). Glacial refuges for three-spined stickleback in the Iberian Peninsula: mitochondrial DNA phylogeography. 
rabbitfish Siganus rivulatus. Journal of Experimental Marine Biology and Ecology, 348(1), 183-190.

Schaarschmidt, T., Meyer, E., \& Jürss, K. (1999). A comparison of transport-related gill enzyme activities and tissue-specific free amino acid

of Baltic Sea (brackish water) and freshwater threespine sticklebacks, Gasterosteus aculeatus, after salinity and tem- perature acclimation. Marine Biology, 135(4), 689-697.

Schluter, D. (1996). Adaptive radiation along genetic lines of least resis- tance. Evolution, 50(5), 1766-1774.

Schluter, D. (2000). The ecology of adaptive radiation. Oxford, UK: Oxford University Press.

Schluter, D., \& Nagel, L. M. (1995). Parallel speciation by natural selection. The American Naturalist, 146(2), 292-301.

Schulte, P. M. (2001). Environmental adaptations as windows on molecular evolution. Comparative Biochemistry and Physiology Part B: Biochemistry and Molecular Biology, 128(3), $597-611$.

Smith, C., Spence, R., Barber, I., Przybylski, M., \& Wootton, R. J. (2014). The role of calcium and predation on plate morph evolution in the three-spined stickleback (Gasterosteus aculeatus). Ecology and Evolu-tion, 4(18), 3550-3554.

Spence, R., Wootton, R. J., Przybylski, M., Macdonald, K., \& Smith, C. (2012). Calcium and salinity as selective factors in plate morph evolu- tion of the three-spined stickleback (Gasterosteus aculeatus). Journal of Evolutionary Biology, 25, 1965-1974.

Spence, R., Wootton, R. J., Barber, I., Przybylski, M., \& Smith, C. (2013). Ecological causes of morphological evolution in the three-spined stick- leback. Ecology and Evolution, $3(6), 1717-1726$.

Spoljaric, M. A., \& Reimchen, T. E. (2007). 10000 years later: Evolution of body shape in Haida Gwaii three-spined stickleback. Journal of Fish Biology, 70(5), 1484-1503.

Taugbøl, A., Arntsen, T., Østbye, K., \& Vøllestad, L. A. (2014). Small changes in gene expression of targeted osmoregulatory genes when exposing marine and freshwater threespine stickleback (Gasterosteus aculeatus) to abrupt salinity transfers. PLoS One, 9(9), e106894.

Taylor EB, McPhail D (2011). Prolonged and burst swimming in anadro- mous and freshwater three spine stickleback, Gasterosteus aculeatus. Canadian Journal of Zoology, 64(2): 416-420.

Tudorache, C., Blust, R., \& De Boeck, G. (2007). Swimming capacity and energetics of migrating and non-migrating morphs of three-spined stickleback Gasterosteus aculeatus L., and their ecological implication. J. Fish Biology, 71(5), 1448-1456.

Tsuzuki, M. Y., Strüssmann, C. A., \& Takashima, F. (2008). Effect of salinity on the oxygen consumption of larvae of the silversides Odontesthes hatcheri and bonariensis (Osteichthyes, Atherinopsidae). Brazilian Archives of Biology and Technology, 51(3), 563-567.

Vila, M., Hermida, M., Fernández, C., Perea, S., Doadrio, I., Amaro, R., \& San, M. E. (2017). Phylogeography and conservation genetics of the lbero-Balearic three-spined stickleback (Gasterosteus aculeatus). PLoS One, 12(1), e0170685.

Voje, K. L., Mazzarella, A. B., Hansen, T. F., Østbye, K., Klepaker, T., Bass, A., \& Vøllestad, L. A. (2013). Adaptation and constraint in astickleback radiation. Journal of Evolutionary Biology, 26(11), 2396-2414.

Walker, J. A. (1997). Ecological morphology of lacustrine threespine stick- leback Gasterosteus aculeatus L. (Gasterosteidae) body shape. Biological Journal of the Linnean Society, $61(1), 3-50$.

Watt, W. B. (1985). Bioenergetics and evolutionary genetics: opportunities for new synthesis. The American Naturalist, 125(1), 118-143.

Wiig, E., Reseland, J. E., Østbye, K., Haugen, H. J., \& Øllestad, L. A. (2016). Variation in lateral plate quality in threespine stickleback from fresh, brackish and marine water: A micro-computed tomography study. PLoS One, 11(10), e0164578.

Willacker, J. J., Von Hippel, F. A., Wilton, P. R., \& Walton, K. M. (2010). Classification of threespine stickleback along the benthic-limnetic axis. Biological Journal of the Linnean Society, 101(3), 595-608.

Williams, D. D., \& Delbeek, J. C. (1989). Biology of the threespine stickle- back, Gasterosteus aculeatus, and the blackspotted stickleback, G. wheatlandi, during their marine pelagic phase in the Bay of Fundy, Canada. Environmental Biology of Fishes, 24(1), 33-41.

Williams, J. E., Johnson, J. E., Hendrickson, D. A., Contreras-Balderas, S., Williams, J. D., Navarro-Mendoza, M., \& Deacon, J. E. (1989). Fishes of North America endangered, threatened, or of special concern. Fisher- ies,14(6), 2-20.

Woo, N. Y., \& Kelly, S. P. (1995). Effects of salinity and nutritional status on growth and metabolism of Sparussarba in a closed seawater system. Aquaculture, 135(1), 229238.

Wootton, R. J. (1976). Biology of the sticklebacks. London: Academic Press. Yang, W. K., Hseu, J. R., Tang, C. H., Chung, M. J., Wu, S. M., \& Lee, T. H.

(2009). $\mathrm{Na}+/ K_{+}-A T P a s e ~ e x p r e s s i o n$ in gills of the euryhaline sailfin

molly, Poecilia latipinna, is altered in response to salinity challenge. Journal of Experimental Marine Biology and Ecology, 375(1), 41-50. 